INTERDISCIPLINARIA ARCHAEOLOGICA NATURAL SCIENCES IN ARCHAEOLOGY

\title{
Geophysical Survey of the Hillfort Staré Zámky near Brno-Líšeň, Czech Republic
}

\author{
Peter Milo ${ }^{\mathrm{a}}$, Tomáš Tencer ${ }^{\mathrm{a}}$, Michal Vágner ${ }^{\mathrm{a}}$, Michaela Prišśákováa ${ }^{\text {Igor Murín }}{ }^{\mathrm{a}}$ \\ ${ }^{a}$ Institute of Archaeology and Museology, Faculty of Arts, Masaryk University, Arna Nováka 1, 60200 Brno, Czech Republic
}

\section{ARTICLE INFO}

\section{Article history:}

Received: $7^{\text {th }}$ May 2020

Accepted: $13^{\text {th }}$ October 2020

DOI: http://dx.doi.org/10.24916/iansa.2020.2.4

Key words:

Early Medieval Period

hillfort

non-destructive methods

magnetometry

ground-penetrating radar

electrical resistivity tomography
$A B S T R A C T$

The aim of this paper is to present the results of geophysical surveys at the Staré zámky site near Brno-Líšeň, which were carried out in 2019. Electrical resistivity tomography, georadar survey and large-scale magnetic prospection were all carried out there. The primary task of the first two methods was to investigate the inner structure of the still-existing ramparts and to identify their individual structural elements. The magnetic survey focused on the identification of areas where potential archaeological features can be found - together with the identification of previously-unknown fortifications. The surveys were successful: we have found numerous settlement features from different phases of settlement, an early medieval cemetery and fortifications of various types, sizes and state of preservation. The results of previous archaeological research of the site played an important role for interpretation of the geophysical data. Together these results provide important insights into the study of the complex fortified settlement of Staré zámky. Despite our results, some questions which cannot be answered by geophysical research alone remain unanswered.

\section{Introduction}

This article discusses the results of geophysical surveys carried out at the archaeological site of Staré zámky near Brno-Líšeň, Czech Republic. The research, undertaken within the framework of the project "Early Medieval hillforts in the light of non-destructive investigation", as the name suggests, aims to extend our knowledge about Central European Early Medieval fortified sites using a wide range of non-invasive prospection methods. The main task was to answer questions related to the layout of the features inside the hillforts and their immediate surroundings, as well as the extent and density of inhabitation and the nature of the fortification systems. Staré zámky proved to be a suitable example site to demonstrate the contribution of various geophysical prospecting methods in gaining new knowledge about an area that has been already intensively archaeologically excavated in the past.

\section{The site and its context}

The poly-cultural site "Staré zámky" is located approximately $1.5 \mathrm{~km}$ to the northeast of the centre of Brno-Líšen suburb. It is situated on a prominent rocky promontory formed by conglomerates, oriented with its longer axis in a northwest to southeast direction. Approximately in the middle of the promontory there is a narrow, approximately $30 \mathrm{~m}$ wide, neck. From here, the promontory extends towards the southeast into an irregular isosceles triangle with a total area of approximately 4 ha. The northern, eastern and southern sides of the promontory are bordered by steep, partly-rocky hillsides (elevation approximately $60 \mathrm{~m}$ ), which are wrapped around by a small watercourse called "Řícka". From the western side, the promontory is bounded by a steep ravine that rises towards the northwest before becoming a gentlysloping plateau.

The oldest traces of settlement can be dated back to the Neolithic period. However, archaeological excavations failed to identify a single settlement feature from this period. Significantly more-intensive settlement came with 
the Eneolithic period. At that time, there was a settlement protected by a rampart and ditch (Medunová-Benešová, 1964). Further traces of settlement have been found from the Bronze and Iron Ages, as well as from the Roman and Migration periods.

The largest growth in settlement came during the Early Medieval Period. The oldest evidence of the Early Medieval settlement comes from the $7^{\text {th }}$ to $8^{\text {th }}$ century, when in addition to the material finds, several housing features and remains of fortifications in the form of a wooden palisade have been found (Procházka, 2009, pp.152-157; Stan̆a, 1972, pp.111-114). The large area (approximately $4 \mathrm{ha}$ ) of the promontory was surrounded by a woodearth structure with a frontal stone wall in the $9^{\text {th }}$ century (Procházka, 2009, pp.152-159; Staňa 1972, pp.115-117). Its remains are still preserved on the northern and eastern side of the promontory, which can be described as the acropolis of the hillfort. Behind the narrow neck of land to the northwest of the acropolis was a bailey ("Bailey I"), which was approximately 1 ha in size and triangular in shape. From the northwest it was surrounded by a rampart, possibly of a stone structure, but the perimeter of the promontory was apparently not protected (Procházka, 2009, p.157; Staňa, 1972, p.136). Further to the northwest there stood another bailey ("Bailey II"), which was fortified by a massive earthen rampart with a ditch on the north-western side. The preserved rampart itself is over 300 metres long. In the south, it emerges from the forest to a field where it has been ploughed up, but it continues in the form of an indistinct terrain wave towards the presentday Líšeň cemetery, where its further course then becomes problematic (Procházka, 2009, p.157; Staňa, 2000, p.201). The size of Bailey II is not clear to us, but according to the known facts and configuration of the terrain, we estimate it to be approximately 10 ha.

Associated with the existence of an Early Medieval hillfort, there was are also a large number of archaeologically-recorded residential features excavated, both habitable and economic (Staňa, 1972; 2000, p.201). In the north-western part of the acropolis it is considered that there was a fenced area, which Staňa (1972, p.139) describes as a magnate court. Within Bailey II, part of a skeletal burial ground (dated to the $9^{\text {th }}$ century) has been uncovered (Poulík, 1948-1950, pp.103-104). At the turn of the $10^{\text {th }}$ century, the fortified settlement was hit by a large fire, which may be associated with a violent invasion (Staňa, 1972, p.154; 2000, p.201). Sometime at the beginning of the $10^{\text {th }}$ century, shortly after the demise of the hillfort, a smaller fortified settlement was built at the acropolis area. Subsequently, during the $10^{\text {th }}$ century, a short "hiatus" in settlement (Kalčík, 2013), or a period of only sparse settlement of the site has been predicted (Procházka et al., 2011, p.497; Staňa, 1972, pp.157-158; 2000, pp.203-206). During the second half of the $11^{\text {th }}$ century, settlement of the site started to decline (Kalčík, 2013, pp.234-235; 2015, p.193).

\section{Archaeological excavation and geophysical research of the hillfort}

The Staré zámky site was archaeologically intensively investigated in the past. In 1863, several human skeletons and archaeological artifacts were found during ploughing. In 1890-91, a local archaeologist, Martin Kř́iž, conducted the first excavation on the site. A total of 40 detection pits, two 124-metre-long probes and several cuts through the rampart were carried out (Poulík, 1960, p.132). During 1948-49, under the leadership of Josef Poulík, Bailey I and the neck of land between Bailey I and the acropolis of the hillfort was excavated. In total, an area of approximately $2250 \mathrm{~m}^{2}$ was uncovered. A part of the $9^{\text {th }}$ century skeleton burial ground was also excavated (Poulík, 1949). Between 1953 and 1965, the most extensive stage of excavation so far was carried out, uncovering an area of $5250 \mathrm{~m}^{2}$. On the promontory of the hillfort, excavation cuts on the perimeter wall. The excavation also uncovered the remains of prehistoric and Early Medieval settlement in the form of housing features, ditches and the rest of two routes dated to the Bronze Age and Early Medieval period (Benešová, Staňa, 1959, pp.166-174). Since then, no archaeological excavation has been carried out on this site. However, recently, the number of findings obtained with the help of metal detectors originating from the area of the hillfort, or its immediate vicinity, has substantially increased (e.g. Vachůt et al., 2013).

More than half a century has passed since the last excavations were conducted on the site. The findings were partially processed, and the old research has been reviewed and summarized (Kalčík, 2013;2015), but no new information has been added that could broaden our knowledge. The geophysical survey planned for this site in 2019 was to erase this shortfall. Given the curtailed possibilities for archaeological methodology, such as the limited size of the surveyed area, or the costly and time-consuming excavation of the fortifications, the use of geophysics was justifiable. A geophysical survey enables the identification of subsurface structures of an archaeological nature in a relatively short time. Moreover, as it is non-destructive, it leaves the site under investigation intact for further research in the future.

The aim of the geophysical measurements at Staré zámky was to broaden our knowledge of the intensity and character of the settlement, as well as the fortification system of the hillfort. Electrical resistivity tomography (ERT) and georadar (GPR) survey were carried out, focusing on the preserved remains of the hillfort's fortification elements the ramparts and ditches. There was also a magnetic field survey, which focused on the accessible area in the acropolis and both bailies.

The role of ERT and GPR prospection was to identify the internal structure of the rampart fortifications, or to focus on the identification of adjacent ditches and determination of their potential extent and depth. A visual survey identified the two most suitable places. The first one was located on the eastern edge of the acropolis and the second in the northern part of the outer rampart of Bailey II (Figure 1). 
Figure 1. Localisation of archaeological excavations and geophysical prospections at the Staré zámky hillfort. The polygons of the excavation grid are based on the site reports (Staňa, 1996, Figure 4) and (Kalč́́k, 2015). Spatial localization of the excavated areas is based on an orthophoto map from the mid$20^{\text {th }}$ century (ČÚZK).

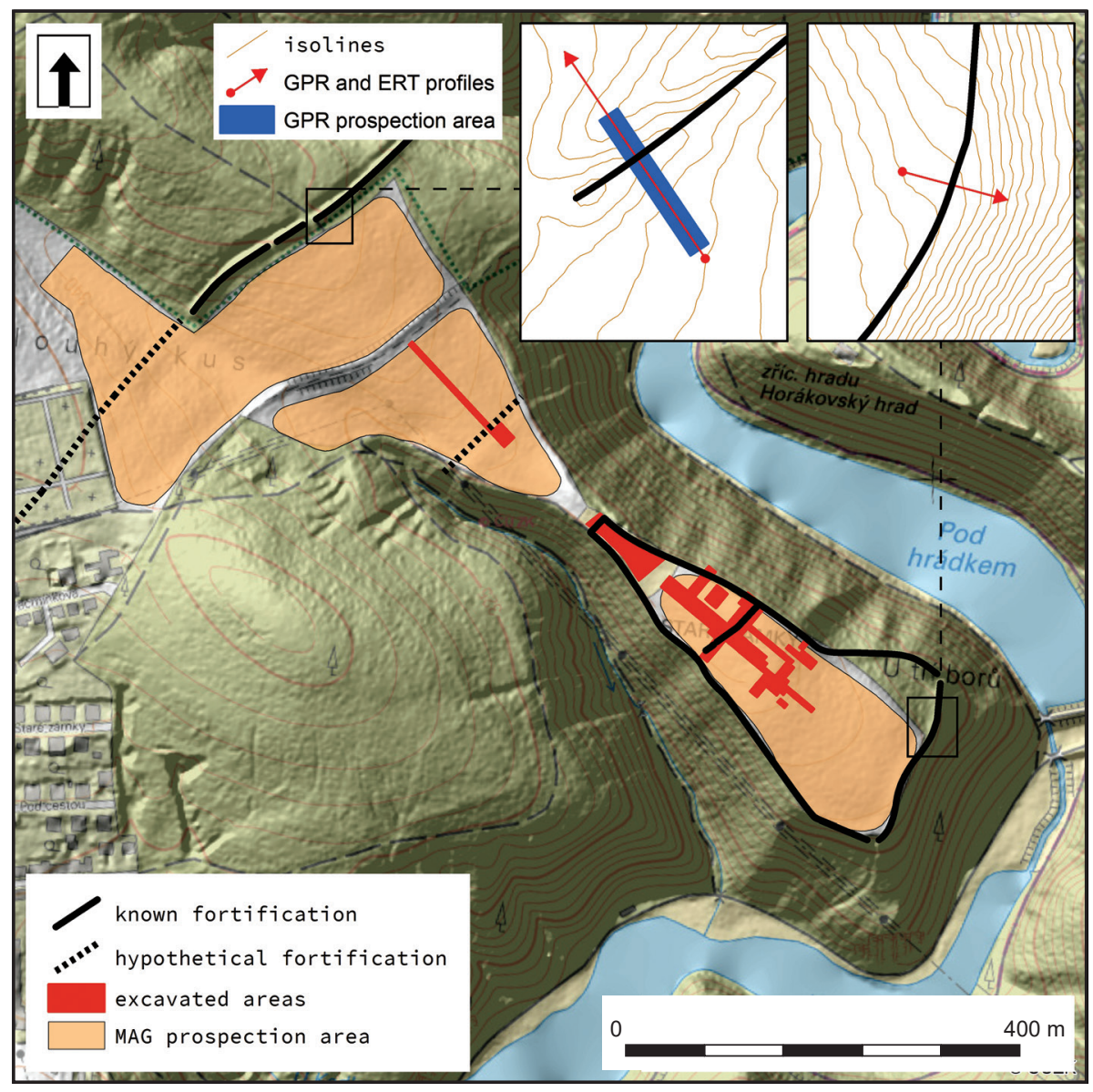

For the purpose of georadar surveying, a X3M Ramac georadar (Geoscience AB Malå), with two shielded antennae with a central frequency of 250 and $500 \mathrm{MHz}$, was used. On the eastern edge of the acropolis, due to the dense vegetation, only a single profile approximately $18 \mathrm{~m}$ in size was measured. On the outer rampart of Bailey II only one $46 \mathrm{~m}$ long profile was measured, the surveyed area being $4 \times 30 \mathrm{~m}$. The spacing between the individual measurement lines was $0.5 \mathrm{~m}$ (Figure 1). GPR data collected throughout the area were evaluated using ArchaeoFusion software (University of Arkansas), Easy 3D software (Geoscience AB Malå) and GPR Slice software (Geophysical Archaeometry Laboratory). Horizontal time/depth cuts were exported in raster form (JPEG) to ArcGIS (ESRI), where they were georeferenced, interpreted and the identified anomalies further digitized into a vector plan. Vertical time/depth cuts were processed using RadExplorer software (v. 1.42; Geoscience AB Malå) and vectorized in Adobe Illustrator CS6.

The ERT prospection was performed using the ARES 850W apparatus (GF Instruments Brno). At the eastern edge of the acropolis a 26-metre-long profile was measured. On the outer rampart of Bailey II, a 47-metre-long profile was measured (Figure 1). Three types of configurations were used - Wenner, Schlumberger and dipole-dipole. RES2DINV software (GEOTOMO, Malaysia) was used for data processing, where both the extreme values were removed, and the apparent resistivity values were inverted to the actual resistivity values. Topographic correction was applied to the resulting data and the resulting model was created showing the real distribution of the specific electrical resistivity in the given profile.

Magnetometry is the most suitable geophysical method for resolving issues related to settlement activities, as it is able to explore large areas in a small amount of time and at the same time identify a wide range of archaeological structures. The total area investigated at the Staré zámky hillfort reached 12.01 ha (acropolis: 3.36 ha; Bailey I: 0.81 ha; Bailey II: $6.87 \mathrm{ha}$; area outside of fortification: $0.97 \mathrm{ha}$; Figure 1). The survey was carried out with a fluxgate magnetometer LEA MAX (Eastern Atlas, Germany). The instrument is designed as a gradiometer. Due to the flat terrain it was possible to use ATV mode (the instrument was pulled by a quad). Ten fluxgate probes (FEREX CON 650, Foerster, Germany) configured 0.5 metres apart were used for the measurements. The density of the magnetic measurements was $0.5 \mathrm{~m}$ on the $\mathrm{X}$ axis and $0.1 \mathrm{~m}$ on the $\mathrm{Y}$ axis (measurement direction). The measured data were collected together along with spatial information from the GNSS receiver - Trimble R-10 model 2 (Trimble, USA). Measurement data were processed using the standard procedure in LEAD2 program. The magnetic field intensity map (magnetogram) in nanoTesla (nT) units was then smoothed by averaging. ArcGIS Desktop 10.7 (ESRI) software was used to present and interpret the results. 


\section{New insights about the fortification system of the hillfort}

The preserved remains of the hillfort's fortifications are only fragmentary. The fortifications that were located in agricultural areas no longer exist. They have been ploughed over and levelled with the surroundings. Their existence is known to us based only on the findings of earlier archaeological excavations. However, their exact location in the field is problematic. The ramparts and ditches that were located in the forested part of the site have also been only partially preserved. The acropolis fortifications are visible as low terrain waves only in the northern and eastern parts of the promontory. Over the rest of the acropolis, the rampart of the promontory has been completely eroded. The rampart that separated the acropolis from Bailey I, and the wall between the first and second bailey, have also been levelled. The only well-preserved fortification at the present time is the wall protecting Bailey II from the northwest; however, this no longer exists outside of the forest.

The aim of the geophysical surveys was to extend our existing knowledge of the site's fortification system. We focused on addressing issues related to the exact location of fortifications, as well as on the survey of the internal structure and state of preservation of the existing parts of walls.

\subsection{Acropolis}

The oldest fortification on the site was made as early as the Eneolithic period. From this period, we know about an enclosing ditch, which was partially excavated (MedunováBenešová, 1964). It was also recorded in a magnetic survey (Figures 3 and 4). At a length of about $65 \mathrm{~m}$, it passes through the central part of the acropolis in a north-south direction. In three places it is interrupted by later interventions. One of these could be an entrance. The ditch is missing in the geophysical data on the edges of the promontory as it has apparently deteriorated naturally. Hallstatt fortifications had been placed in the narrowest part of the promontory (Poulík, 1948-50, p.101), but geophysical research did not take place there.

The question of the existence of a medieval fortification older than the rampart from the $9^{\text {th }}$ century is a problematic one. It is often connected with a palisade recorded on the edge of the acropolis, but its dating before the $9^{\text {th }}$ century is questionable (Procházka, 2009, pp.155-157). Geophysical research in this regard did not have the opportunity to bring new information.

From the previous excavations, we are best informed about the perimeter fortifications of the acropolis dating back to the $9^{\text {th }}$ century (Figure 2$)$. On the artificial terrace on the slope, foundations of a stone wall approximately 1 metre wide were found. A substantial part of it has collapsed down the slope. Log chambers filled with clay were adjoined from the inner side of the rampart. A ramp made of piled up clay was also connected to the structure from its inner side. Approximately at the beginning of the $10^{\text {th }}$ century, the foundation of a drylaid stone wall, which forms a part of the younger wall, was embedded in the destroyed fortifications (Procházka, 2009, pp.152 and 155, Figure 95).

The magnetic survey was only carried out in the open area, yet it managed to detect a part of the perimeter wall. It showed in the data as a linear anomaly with high magnetic values. Marginally, it can be observed at the eastern edge of the surveyed area. Most of it was captured at the southwestern edge of the acropolis (Figures 3 and 4). High magnetic values $(-40 /+100 \mathrm{nT})$ gathered within the area of the rampart indicate traces of high heat. This is fully in line with the findings of the excavation, which showed that at the

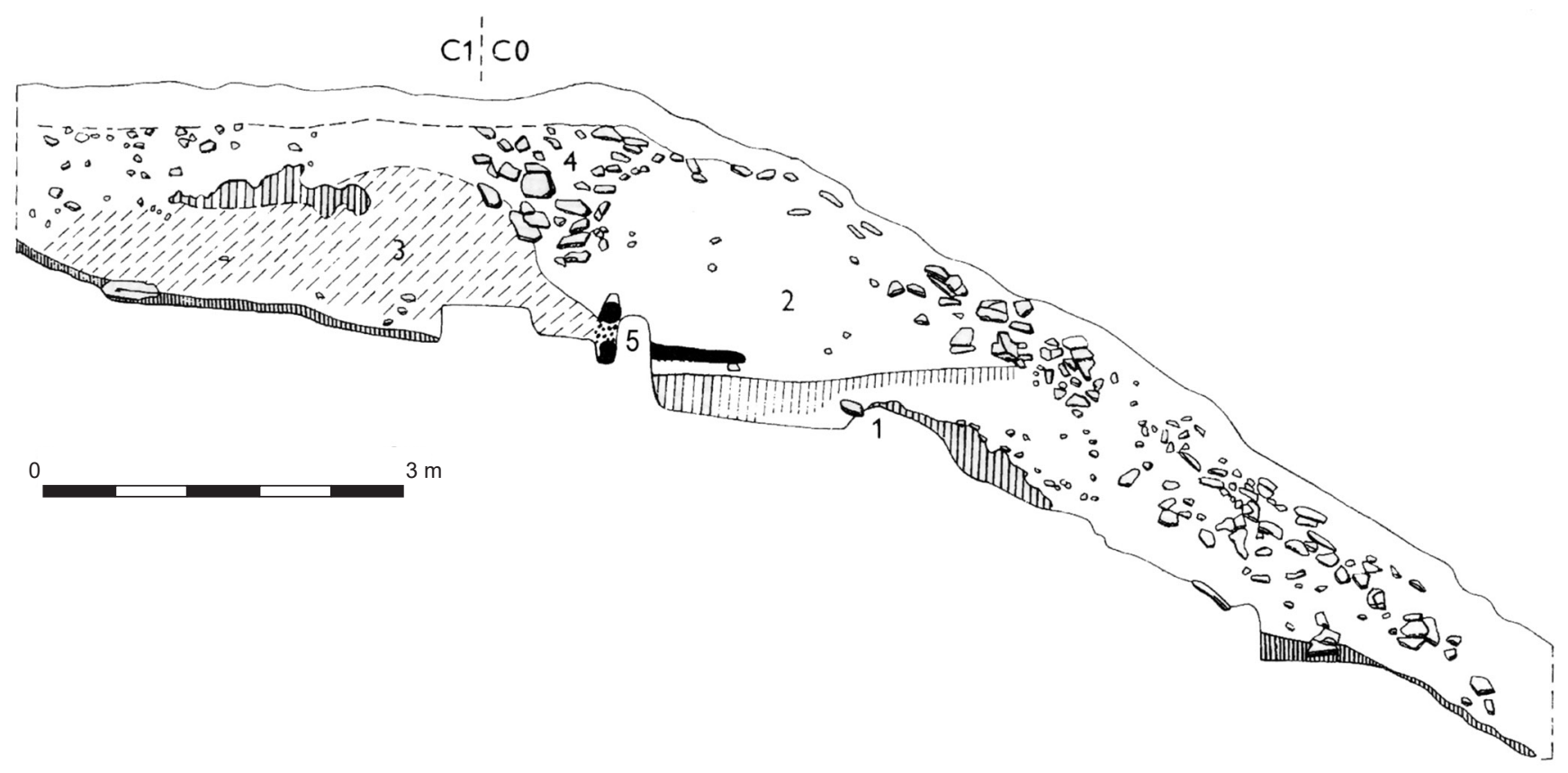

Figure 2. Western profile of a rampart cut in the north-eastern part of the acropolis, 1 - remains of the frontal stone wall, 2 - rampart body with a box construction, 3 - clay embankment, 4 - younger stone wall, 5 - remnants of charred wood (Procházka, 2009, Figure 95). 
Figure 3. Acropolis. Magnetogram of the surveyed area.

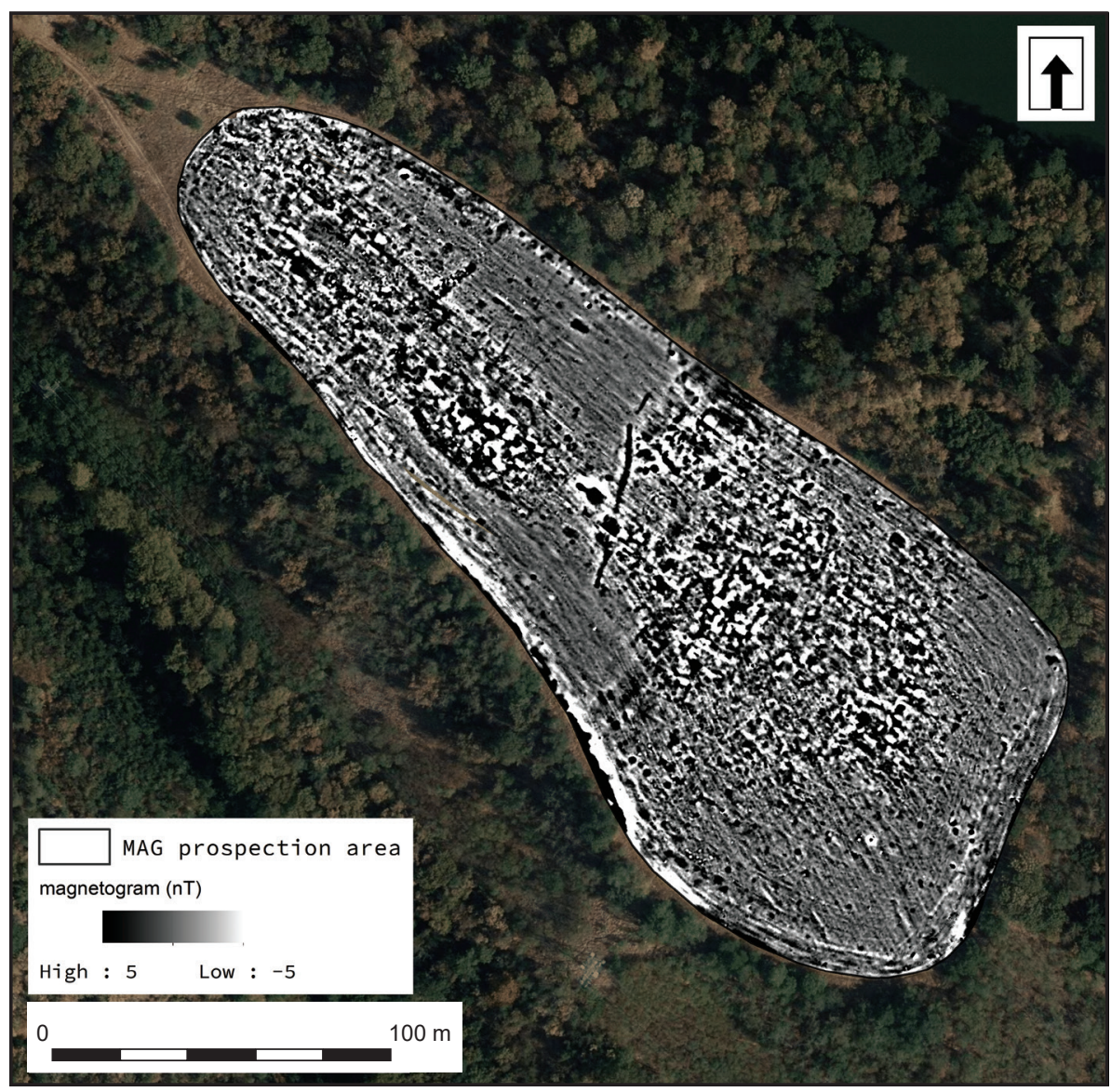

Figure 4. Acropolis. Archaeological interpretation of the magnetic prospection data.

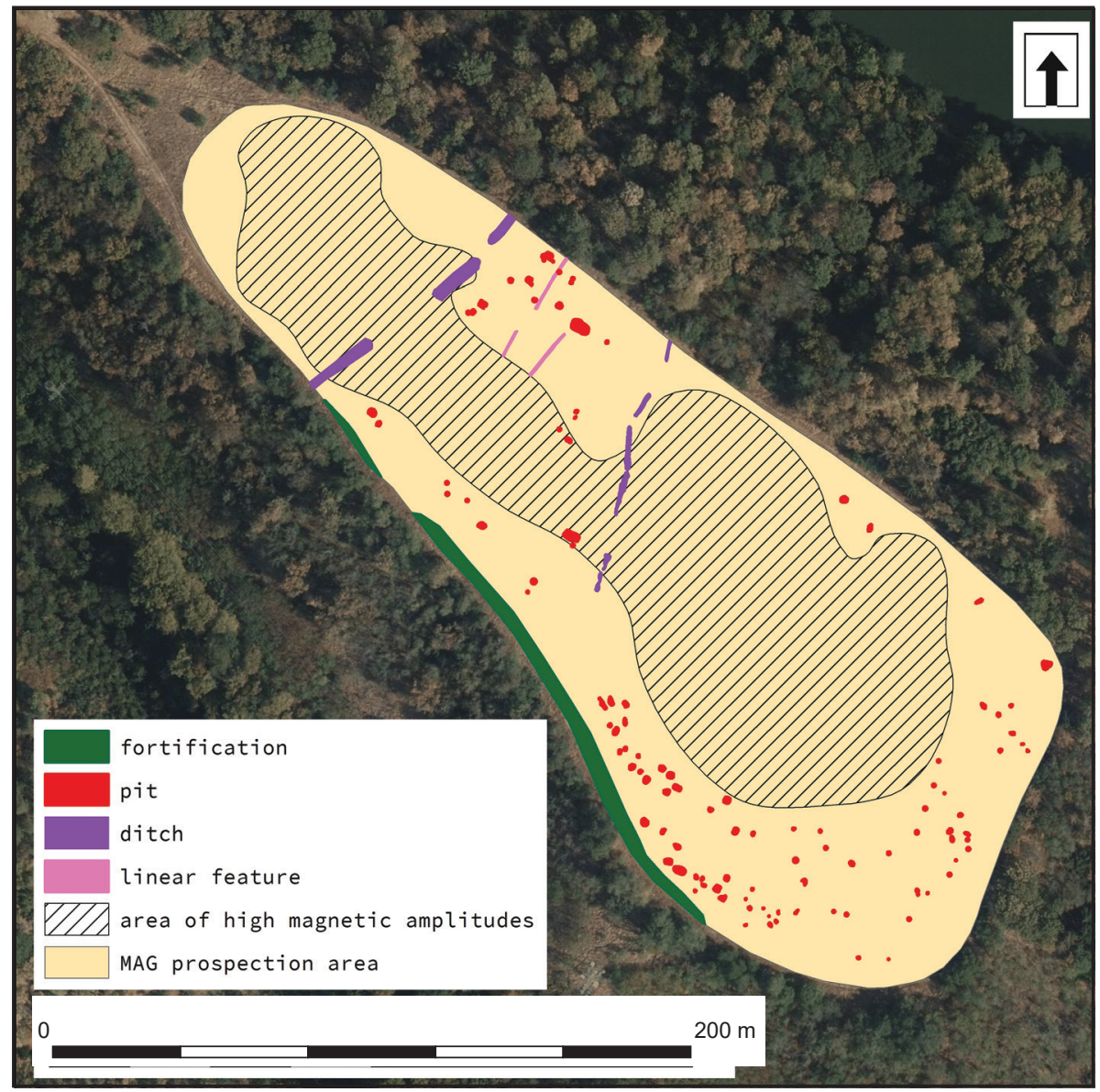



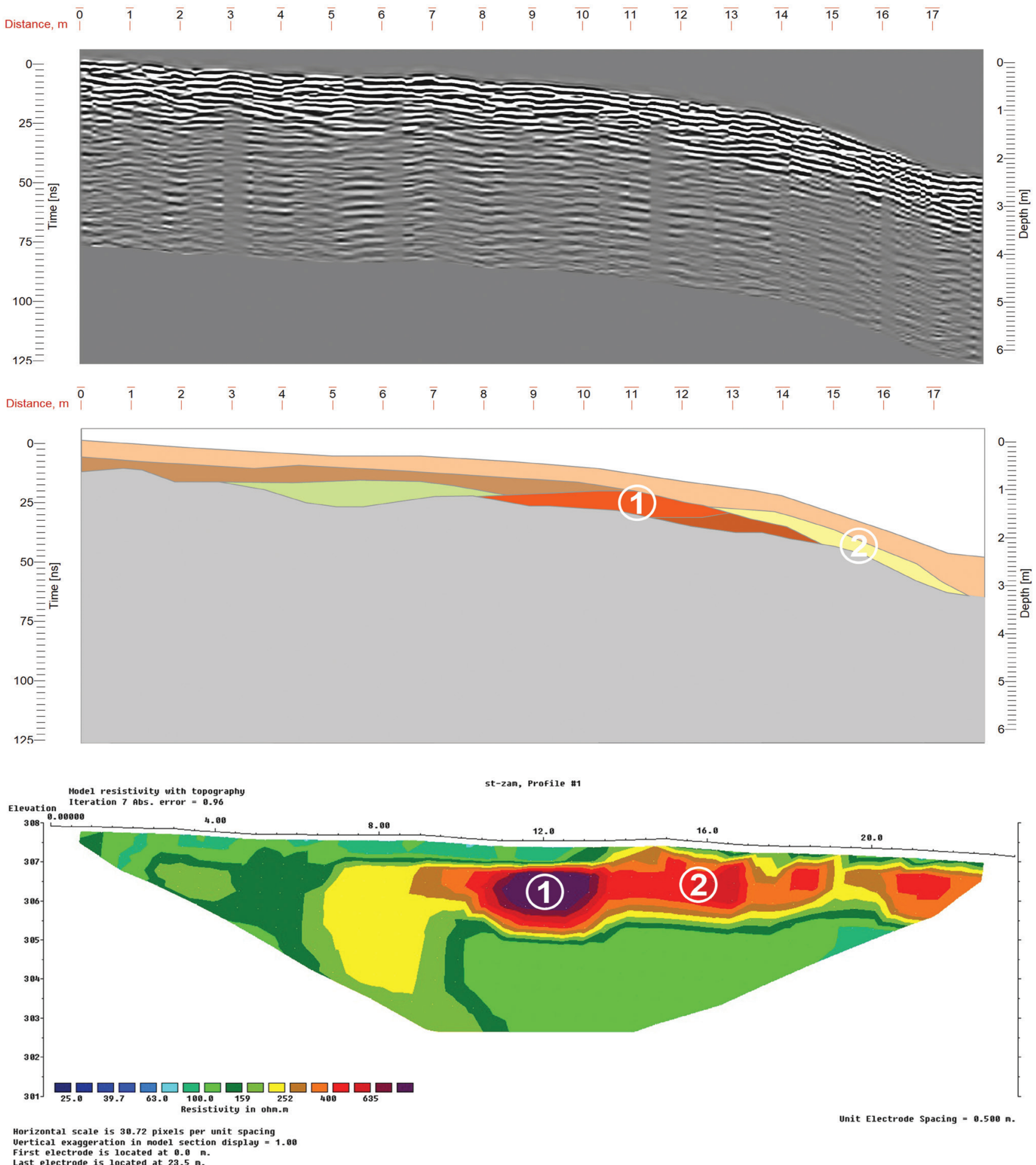

Figure 5. Results of GPR and ERT wall measurements on the acropolis. Above: GPR vertical time / depth section (500 MHz centre frequency antenna). Middle: interpretation plan of GPR measurement results. Bottom: the resulting model showing the real distribution of the specific electrical resistivity on the measured profile, obtained by the ERT method (Schlumberger configuration). 1. preserved body of the rampart, 2. destructive layer from the outer side of the rampart.

turn of the $10^{\text {th }}$ century the perimeter wall of the acropolis was hit by a large fire and in some places, it was completely destroyed. This is evidenced by burnt wooden crates as well as a layer of burnt clay up to 1 metre thick (Procházka, 2009, p.155; Staňa, 1972, p.154; 2000, p.201). On the southwestern edge of the acropolis (in the area where the burnt-down wall was best recorded by magnetic research), an excavation in 1965 captured a layer of burnt-earth which was part of the destroyed wall just below the topsoil (Procházka, 2009, p.155). The geophysical survey managed to determine the 
course of the fortification in the part where no surface traces were preserved. We also found that the fire we knew from the excavation was not local, but that it destroyed at least the entire southwest and probably the southern and eastern parts of the wall as well.

The GPR prospection and the ERT's main task was to ascertain the state of preservation of the acropolis (Figure 5). The GPR survey was able to capture homogeneous layers that can be interpreted as remains of the body of the wall. The anomaly with higher electrical resistivity values measured with ERT represents the remnants of the original stone-rich fortification. At the same time, it is possible to observe the destruction layer that has spread down the slope. Therefore, the ERT and GPR prospections fully correspond with the results obtained from the excavation.

The ditch intersecting the acropolis in its north-western part is dated back to the first half of the $10^{\text {th }}$ century (Figures 3 and 4). It separated the upper north-western part of the acropolis from its lower south-eastern part. This ditch has been almost completely archaeologically excavated (Kalčík, 2013, p.228; 2015, pp.138-144; Staňa, 1972, p.111). It was also recorded in the magnetic survey. The ditch was found to continue southwest to the edge of the acropolis. During the excavation, the remains of the wall (in the form of its

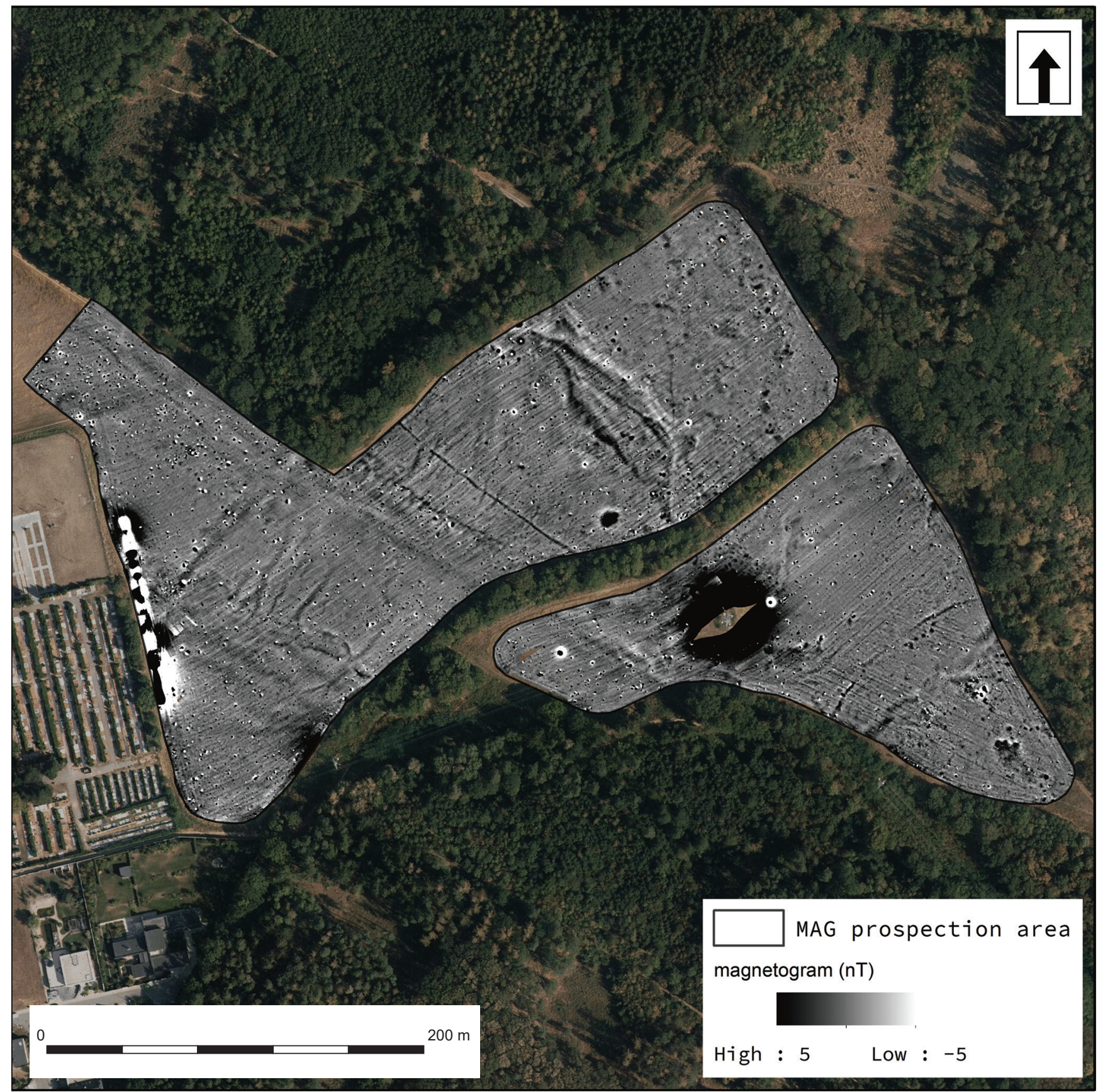

Figure 6. Bailey I and II. Magnetogram of surveyed area. 
destruction in the ditch) were observed only on its northern edge (Procházka, 2009, p.158, Figure 100). No direct evidence of the wall was found elsewhere. Limestone stones, embers or one larger piece of wood found in the backfill are only indirect indications of the existence of the wall (Kalčík, 2013, p.228). Traces of the wall were not observed in the results of magnetic measurement either. Nevertheless, based on the geophysical research, we can assume that there was a fortification in parallel with the ditch on the north-western side. This is indicated by the absence of archaeological features in a strip approximately $4 \mathrm{~m}$ wide. Today, it could be a completely-levelled fortification that has not interfered with the ploughed intact subsoil.

\subsection{Bailey I}

To the northwest of the acropolis there is a bailey ("Bailey I"), separated from Bailey II by a rampart and probably also by a ditch. It is considered that the fortification there could have even had a stone structure (Procházka, 2009, p.157; Poulík, 1949, p.40; 1948-1950, p.99). The course of the ditch is clearly visible in the magnetic measurement results (Figures 6 and 7). In a slight arc, it crosses the promontory in the recorded length of $106 \mathrm{~m}$, and a width of about $2 \mathrm{~m}$, though it is interrupted in four places. There were no traces of a rampart or a wall directly related to this ditch. However, four features situated in a line about $4 \mathrm{~m}$ behind the ditch from the inner side, indicate the existence of fortifications.

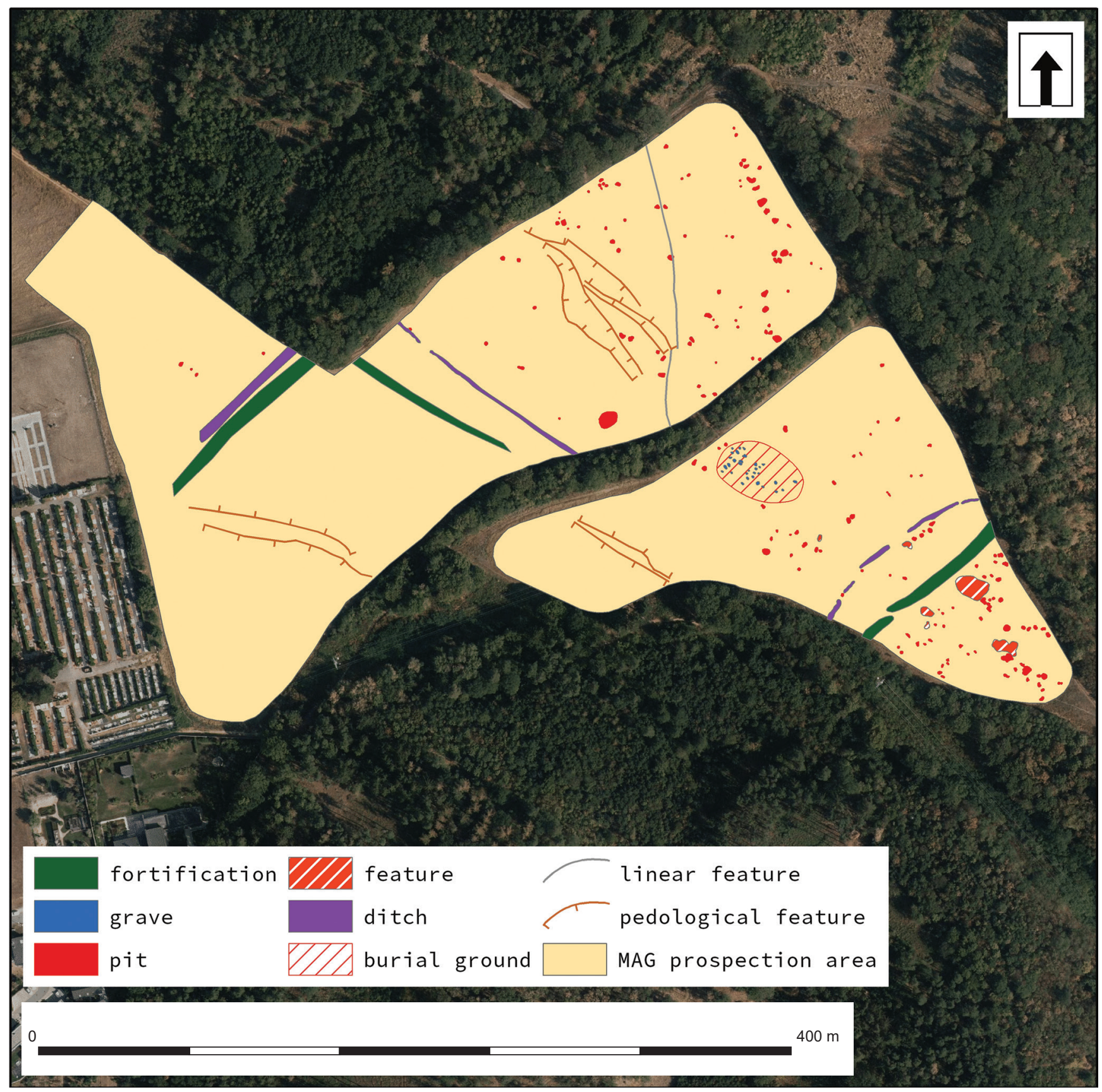

Figure 7. Bailey I and II. Archaeological interpretation of the magnetic prospection data. 

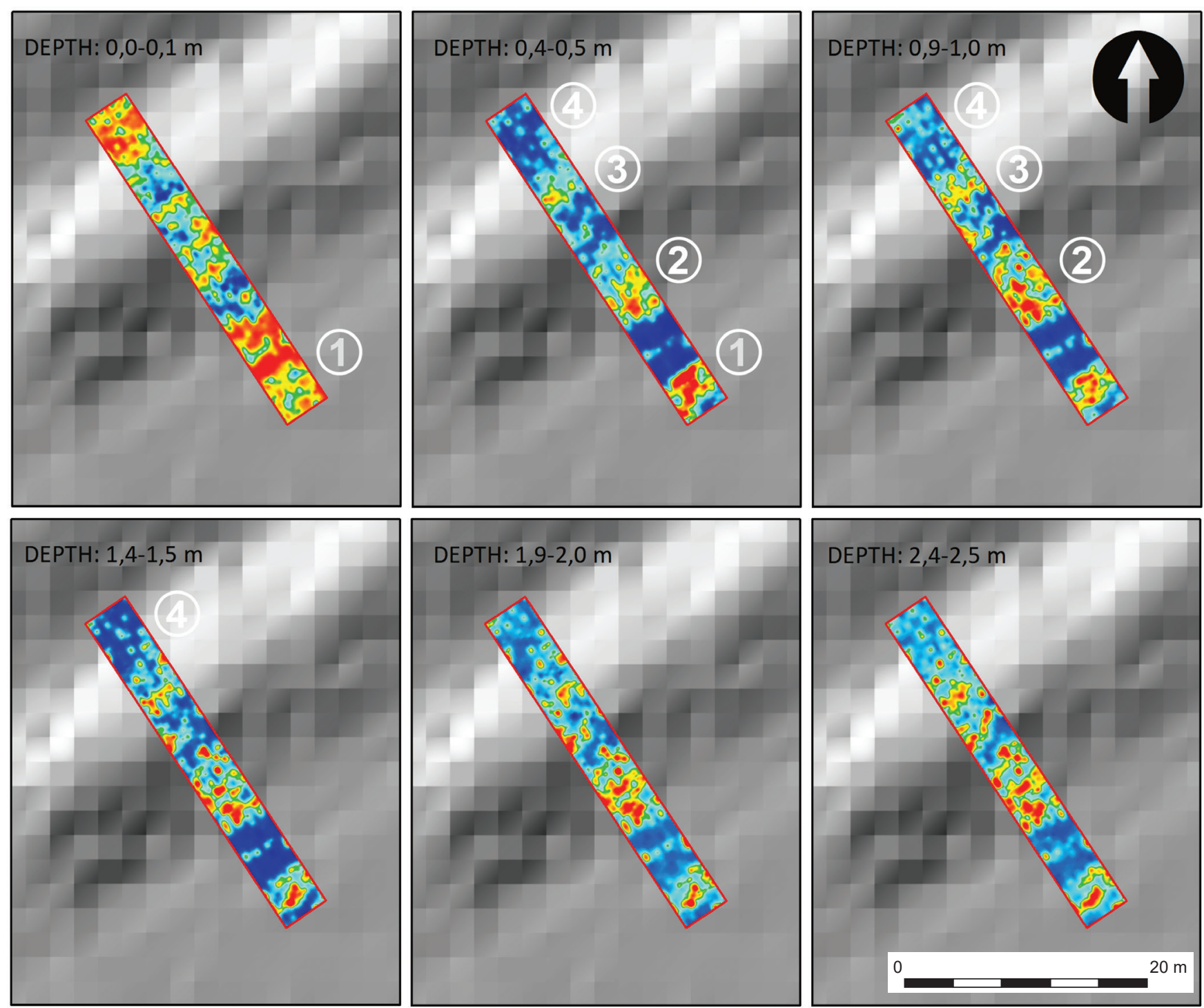

Figure 8. Horizontal time / depth sections of the outer rampart of Bailey II (antenna with a central frequency of $250 \mathrm{MHz}$; background data: DTM5G ČUZK). 1. Recent path; 2. Homogeneous formation on the inner side of the rampart; 3. Homogeneous formation on the outer side of the rampart (a gravel layer?); 4. Ditch.

The nature of a linear structure, situated 20 to $25 \mathrm{~m}$ southeast of the ditch delimiting Bailey I, remains a question. It crosses the promontory, directly from one edge to the other, being in total, some $90 \mathrm{~m}$ long and approximately $6 \mathrm{~m}$ wide. However, it exhibits only mild magnetic values. Archaeological probes have not recorded any significant fortification elements. It is possible that this is a natural, pedological structure, but neither can we fully rule out the possibility that it is a levelled fortification. It could be, for example, only a simple rampart that did not reach topsoil level and was preserved only in the form of a scattered layer that consisted of more magnetic material than the surrounding area. The fact that the number of recorded archaeological features in front of the line was minimal, while the number immediately behind it significantly increased, might indicate its existence (Figures 6 and 7).

In addition to the situation concerning finds of fortifications on Bailey I, it is necessary to add that we are not sure which geophysical survey of the fortifications found represents the wall described during the excavation. The excavation puts the course of fortification into the void between the two geophysical surveys of the detected fortification. This is due to the inaccurate geodetic focus of old archaeological excavations. In the following text, we will start from the premise that the boundary of Bailey I is the detected ditch. A potential fortification situated closer to the acropolis would be considered a new feature. But it could also be that it is the other way around, and the answer to that question can only be provided by further archaeological excavation.

\subsection{Bailey II}

Bailey II is situated in a north-western direction from Bailey I. From the northwest it was protected by a massive rampart with a ditch. The elevation of the rampart compared to the inner surface of the site is $2-2.5 \mathrm{~m}$; when compared 

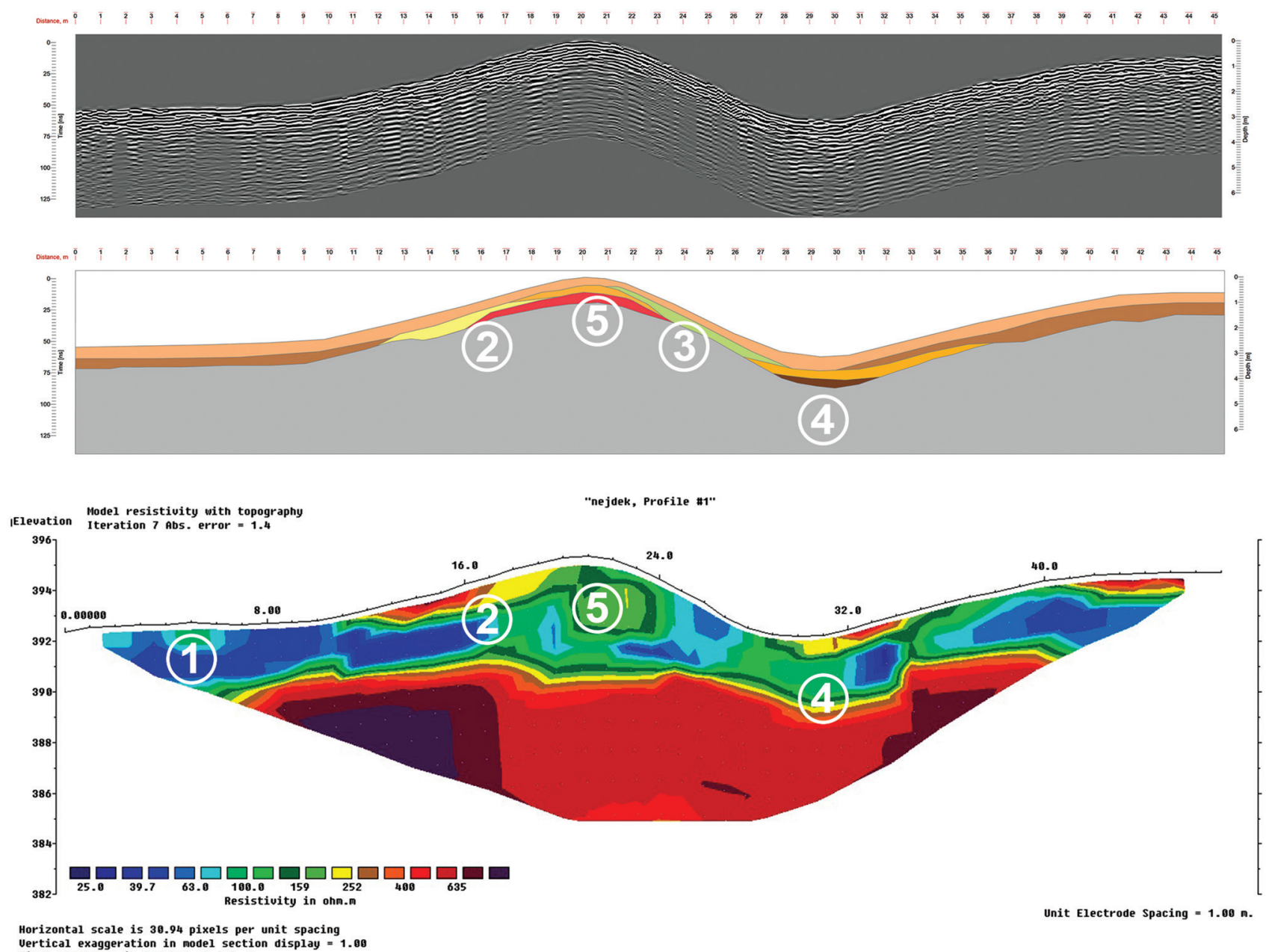

Uertical exaggeration in model section display $=1.00$ First electrode is located at $0.0 \mathrm{~m}$.

Figure 9. Results of GPR and ERT measurements of the outer rampart of Bailey II. Above: GPR vertical time / depth section (500 MHz centre frequency antenna). Middle: interpretation plan of GPR measurement results. Bottom: the resulting model showing the real distribution of the specific electrical resistivity on the measured profile obtained by the ERT method (Schlumberger configuration). 1. Recent path 2. Homogeneous formation on the inside of the rampart; 3. Homogeneous formation on the outside of the rampart (a gravel layer?); 4. Ditch, 5. Rampart body.

to the ditch it is 2.5-4 m (Procházka, 2009, p.157; Staňa, 2000, p.201). During a large-scale GPR survey of the rampart, several larger anomalies were detected. In addition to a recent road, which is located on the surface and passes parallel to the rampart a few meters from its inner side, several homogeneous strata have been identified inside the rampart, both on its outer and inner sides (Figure 8). Based on GPR results, it appears that the rampart body consists only of clay, without the presence of larger stone structures. This would correspond to the findings of archaeological excavations (Procházka, 2009, p.157). The radargram also shows a homogeneous layer on the outside of the rampart, which could be correlated with the gravel layer documented during the excavation (Figure 9). In front of the rampart the GPR survey also managed to capture the remains of a filled ditch, in which it is possible to distinguish a sequence of several strata with a total thickness of less than $2 \mathrm{~m}$. This finding again corresponds to the results of the archaeological excavation, when a layer of alluvium with a thickness of ca. $1.8 \mathrm{~m}$ was recorded in the ditch (Staňa, 1972, p.136).
The results of the ERT confirm the findings of the GPR survey (Figure 9). The wall body is relatively homogeneous. Nevertheless, we can observe the possible presence of material with higher resistivity values. The presence of stone debris cannot therefore be completely ruled out. The surroundings are made of clay. The backfill of the ditch with low electrical resistivity is also made of clay, and in the top layer we can expect some possible stone debris. The high values of resistivity in the deepest layer represent a rocky bedrock.

On its northern side the rampart reaches up to the rather steep slope. To the south, the rampart continues from the forest to the field where it has been ploughed up (Procházka, 2009, p.152; Staňa, 2000, p.201). Measuring the course of the rampart in its ploughed part was one of the main tasks of magnetic prospection. Also, a question arises considering the defence of the Bailey II from the open southern side, where no fortification was recorded.

The rampart and the ditch in the area where they were ploughed appeared in the resulting magnetogram as 
magnetically unimpressive lines (Figure 6). They head further southwest, outside the geophysically surveyed area. It is necessary to admit that if we did not know about the existence of the Early Medieval fortification, the interpretation of the observed linear structure would have been a problematic one. At the same time, it is also important to note that the linear structure of Bailey I, which we have identified as the potential torso of a rampart or wall, also manifested itself in the magnetogram. Such interpretation gains importance following the findings of Bailey II. From this perspective, a linear structure pointing approximately from the corner of the forest to the southeast is also interesting. We cannot exclude the idea that this is the same kind of fortification that would, in this segment, divide the Bailey II into a northern and southern part. However, the linear structure that is 17 to $22 \mathrm{~m}$ northwards, could also be significant (Figures 6, 7). It is a line $1.5 \mathrm{~m}$ in width, which was recorded with a length of $117 \mathrm{~m}$. It is interrupted at one point. In the geophysical data it shows similar properties to the ditch separating the first and second bailey. We therefore cannot exclude the possibility that it is a ditch from the same period, which served as a protection for the southern part of the second bailey. The bailey would thus occupy an area of about 5 ha in this period. Traces of a wall or a rampart behind the ditch were not detected.

\section{Settlement features and activities}

As for the presence of housing features, in the hillfort of Staré zámky they are best documented in the acropolis area, where they were captured by means of archaeological excavation in the form of sunken huts of rectangular and square ground plans, with layers indicating the presence of above-ground buildings: log houses, storage pits of a circular ground plan, housing pits of various shapes and often unknown function, as well as simple stake pits. New insights about the settlement of the hillfort needed to be proven by magnetic research.

We have found out that the intensity of anthropogenic activity varies in different parts of the site. The most intensive traces of settlement were recorded in the acropolis (Figures 3 and 4). Potential archaeological features are concentrated mainly in its north-western and central parts. There is, however, a problem with their chronological classification. As there was a multiphase settlement on the site, we have to count with sunken features from different periods. A closer characterisation of the Medieval settlement remains, therefore, a problematic one. Concentrations of anomalies with high magnetic values are also questionable. This may be a manifestation of the geological subsoil. However, we cannot fully exclude a significant proportion of archaeological structures in this area. A significant fire horizon is mentioned on the hillfort, as well as ash backfill in the features (Poulík, 1948-50, p.101), which could cause such anomalous (magnetic) manifestations. Traces of past archaeological excavations can be partially traced in the area.

It was not possible to verify the existence of a fenced area, which Staňa $(1972$, p.139; 1985 , p.168) refers to as a noble court from the second half of the $9^{\text {th }}$ century. If this court was, as stated, fortified only by a simple wooden palisade, it is probable that the magnetic survey could not capture it. Likewise, we did not notice any traces of a masonry structure, something which could be expected due to the secondly-used finds of stones with mortar in this area, according to some researchers (Procházka et al., 2011, p.470).

Bailey I is characterized by a large number of potential archaeological features (Figures 6 and 7). Anomalies indicating smaller settlement features as well as large structures, and anomalies indicating burnt-out features or furnaces, were detected here. The largest number of features is concentrated near a linear structure that could represent a fortification.

Structures of a settlement character were also identified in Bailey II (Figures 6 and 7). They point to a scattered type of settlement. The only higher concentration can be observed at the northern edge of the investigated area. Several settlement features are located here in a line running from northwest to southeast. It is probable that they are lined up next to the road that has not been preserved, or as such did not appear in the geophysical data. No archaeological feature was identified in the southern part of the investigated area, i.e. in the area in front of the newly-discovered potential ditch. This area probably served a non-residential purpose.

The important findings on Bailey II include the identification and localization of an early medieval burial ground, which was partially researched in 1948-49. Within two seasons, 46 skeletal graves were discovered there, which were dated to the $9^{\text {th }}$ century based on the grave inventory (Poulík 1948-1950, pp.103-104). More than 20 graves can be observed in the results of the geophysical measurements (Figures 6 and 7). The individual grave-pits are oriented in a northwest-southeast direction and arranged in rows. Given the only approximate location of the old archaeological excavation, it is not possible to say which of the geophysically identified graves have already been archaeologically examined. Another problem is the presence of a high-voltage electric mast just to the southeast of the burial ground, which causes significant interference.

Last, but not least, it is necessary to mention the structures of a pedological and geological character, which can be observed in the form of slight magnetic-line patterns in various parts of the site. However, they did not significantly affect the results of the measurements or the interpretation of archaeological situations.

\section{Final discussion}

The geophysical survey determined the exact course of the already known fortifications, but hitherto unknown fortifications were also recorded (Figure 10). These will need to be verified in the future by archaeological excavation, which may focus on specific features. This is mainly a potential fortification of Bailey I and fortifications delimiting Bailey II 


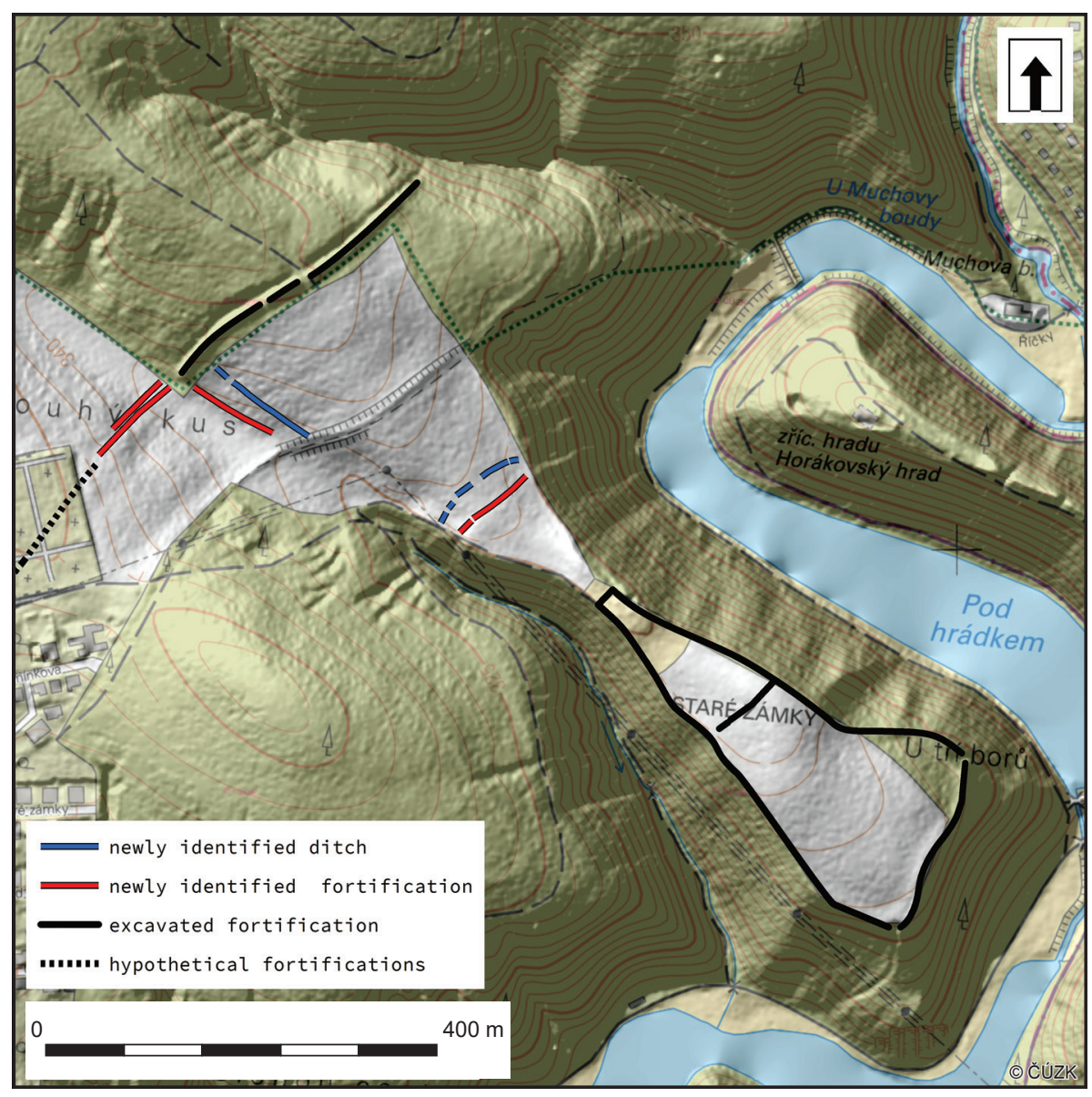

Figure 10. Reconstruction of the fortifications on the Staré zámky hillfort in the $9^{\text {th }}$ and $10^{\text {th }}$ centuries. Comparison of rampart and ditch fortifications from the archaeological excavations and the geophysical survey.

from the south. The development of the fortification system at the site is still not entirely clear to us. The oldest fortification dates back to the Eneolithic period and was located on the acropolis. Sometime in the $8^{\text {th }}$ century, or in the first half of the $9^{\text {th }}$ century, we can assume a fortification of the acropolis with a simple palisade. We expect the greatest expansion in the second half of the $9^{\text {th }}$ century, when we assume the existence of a local power centre of the Great Moravian state. The geophysical survey showed that the archaeological traces of the fire recorded during the archaeological excavation were not local, but that the entire perimeter wall of the acropolis was probably subject to fire.

Two fortifications were attached to the fortified acropolis in the $9^{\text {th }}$ century. Bailey I was protected by a rampart and ditch. The character of the new detected linear structure, situated 20 to $25 \mathrm{~m}$ southeast of the ditch, is questionable. It is possible that it is a natural structure, but it may also be a levelled fortification from an older or younger phase of the settlement. The structure represents the boundary that determines the population density. There are only a few features between it and the ditch delimiting Bailey I. From this structure towards the interior of the bailey, the number of buildings is high and comparable to the population density on the acropolis.

However, most of the ambiguities were associated with Bailey II. From the northwest it was protected by a massive rampart with a ditch. The geophysical survey confirmed its continuation to the south. The linear structure that divides the second bailey into a northern and southern part is interesting. Its interpretation as a fortification is quite uncertain. However, another linear structure runs parallel to it, which in the geophysical data shows similar properties to that of the ditch separating the first and second bailey. It is therefore possible that it is a ditch from the same period, whose task was to protect the second bailey from the south. From this point of view, the fact that no archaeological feature was identified in the southern part of the examined area, i.e. in the area outside the fortified area, is interesting.

\section{Conclusion}

Our knowledge of the settlement of the Staré zámky hillfort and its fortifications has so far been based on the knowledge gained through archaeological excavation, surface collections and surveys by metal detectors. Geophysical research significantly expands our knowledge. The magnetic research conducted brought new evidence of settlement activities on the acropolis and in the bailies. Information on the structure of the ramparts were provided by the ERT and GPR surveys. An important tool in the interpretation of the recorded values was older archaeological excavation, which allowed us to better interpret the geophysical data.

The geophysical survey brought several new insights into the extent of fortifications and settlements at the Staré zámky 
site. In the future, these insights will need to be verified by precise archaeological excavation. Clarification of the character and chronological classification of at least some of the geophysically identified structures will help us to better understand the function of individual parts of the site, as well as to notice the overall development of the settlement and the importance of the site.

\section{Acknowledgements}

The research was undertaken within the framework of the project "Early Medieval hillforts in the light of nondestructive investigation" supported by the Czech Science Foundation (GACR) under Grant No. 18-16153S.

\section{References}

BENEŠOVÁ, A., STAŇA, Č., 1959. Cesta z mladší doby bronzové na Starých Zámcích u Líšně. Archeologické rozhledy, 11, 166-174, 198-200, 206.

ČÚZK. Český úřad zeměměřický a katastrální: https://ags.cuzk.cz/archiv

KALČÍK, L., 2013. Povelkomoravské osídleni hradiska Staré zámky u Lišně. Unpublished thesis, Institute of Archaeology and Museology, Faculty of Arts, Masaryk university, Brno.
KALČÍK, L., 2015. Povelkomoravské osídlení hradiska Staré zámky u Líšně. Die nachgroßmährische Besiedlung des Burgwalls Staré Zámky bei Líšeň. Přehled výzkumů, 56-2, 127-200.

MEDUNOVÁ-BENEŠ̆OVÁ, A., 1964. Eneolitické výšinné sídliště Staré Zámky v Brně-Líšni (Výsledky výzkumů v letech 1953-1959). Památky archeologické, 55/1, 91-155.

POULÍK, J., 1949. Velkomoravské středisko Staré Zámky u Brna. Archeologické rozhledy, 1, 40-51.

POULÍK, J., 1948-1950. Jižní Morava, země dávných Slovanů. Brno.

POULÍK, J., 1960. Staři Moravané buduji svi̊j stát. Gottwaldov.

PROCHÁZKA, R., 2009. Vývoj opevňovaci techniky na Moravě a v českém Slezsku v raném středověku. Brno.

PROCHÁZKA, R., WIHODA, M., ZAPLETALOVÁ, D., 2011. V raném středověku. In: R. Procházka, ed. Dějiny Brna I. Od pravěku k ranému středověku. Brno, pp. 447-560.

STAŇA, Č., 1972. Velkomoravské hradiště Staré Zámky u Líšně. Monumentorum Tutela. Ochrana pamiatok, 8, 100-159.

STAŇA, Č., 1985. Mährische Burgwälle im 9. Jahrhundert. In: H. Friesinger, F. Daim, eds. Die Bayern und ihre Nachbarn. Berichte des Symposions der Kommission für Frühmittelalterforschung vom 25. bis 28. Oktober 1982 in Stift Zwettl, Niederösterreich, Vol. 2. Wien, 157-200.

STAŇA, ¿̌., 1996. Archäologische Erforschung mährischer Höhenburgwälle. In: Č. Staňa, L. Poláček, eds. Internationale Tagungen in Mikulčice III. Frühmittelalterliche Machtzentren in Mitteleuropa. Mehrjährige Grabungen und ihre Auswertung. Brno, pp. 267-281.

STAŇA, Č., 2000. Pronikání Boleslava II. na Brněnsko ve světle archeologických objevů. In: Přemyslovský stát kolem roku 1000. Na pamét knižete Boleslava II. (+ 7. února 999). Praha, pp. 197-208.

VACHŮT, P., VIDEMAN, J., RAJLICHOVÁ, A., 2013. Řezenský obol Oty Švábského a další nové doklady obchodních aktivit $\mathrm{z}$ hradiště Staré Zámky v Brně-Líšni. Numismatický sbornik, 27/2, 191-195. 
